\title{
HispanismeS
}

Revue de la Société des Hispanistes Français

\section{Hacerlo explícito. ARAN y los giros del tiempo en el arte XR}

Le rendre explicite. ARAN et les méandres du temps dans l'art XR

Making it explicit. ARAN and the twists and turns of time in art XR

\section{Miguel F. Campón y José D. Periñán}

\section{OpenEdition}

\section{Journals}

\section{Edición electrónica}

URL: https://journals.openedition.org/hispanismes/440

DOI: 10.4000/hispanismes.440

ISSN: 2270-0765

Editor

Société des Hispanistes Français

\section{Referencia electrónica}

Miguel F. Campón y José D. Periñán, «Hacerlo explícito. ARAN y los giros del tiempo en el arte XR», HispanismeS [En línea], 14 | 2019, Publicado el 01 octubre 2019, consultado el 31 agosto 2021. URL http://journals.openedition.org/hispanismes/440 ; DOl: https://doi.org/10.4000/hispanismes.440

Este documento fue generado automáticamente el 31 agosto 2021.

\section{$\Theta \Theta \Theta$}

Les contenus de cette revue sont mis à disposition selon les termes de la Licence Creative Commons Attribution - Pas d'Utilisation Commerciale - Pas de Modification 4.0 International. 


\title{
Hacerlo explícito. ARAN y los giros del tiempo en el arte XR
}

\author{
Le rendre explicite. ARAN et les méandres du temps dans l'art XR \\ Making it explicit. ARAN and the twists and turns of time in art XR
}

\author{
Miguel F. Campón y José D. Periñán
}

\section{Prólogo}

1 El presente artículo corresponde al texto corregido y ampliado de la conferencia Hacerlo explícito, impartida en el Salón de Actos de la Facultad de Bellas Artes de la Universidad Complutense de Madrid en abril de 2019, dentro del seminario Arte urbano y tecnoesfera. Las imágenes virtuales que lo acompañan fueron realizadas ante el auditorio con un equipo de gafas VR HTC Vive por José Delgado Periñán. La acción no solo funcionaba como complemento visual del discurso, sino que desplegaba, en sí misma, las nociones desarrolladas. Los dibujos se proyectaron a tiempo real junto a imágenes de la primera exposición producida por ARAN ${ }^{1}$, titulada Time and Umwelt ${ }^{2}$, y junto a otras fotografías y referencias a las que aludiremos a lo largo del texto. En él tratamos de establecer los conceptos filosóficos que, hasta el momento, articulan los discursos curatoriales de ARAN. 
Fig. 1 Hacerlo explícito

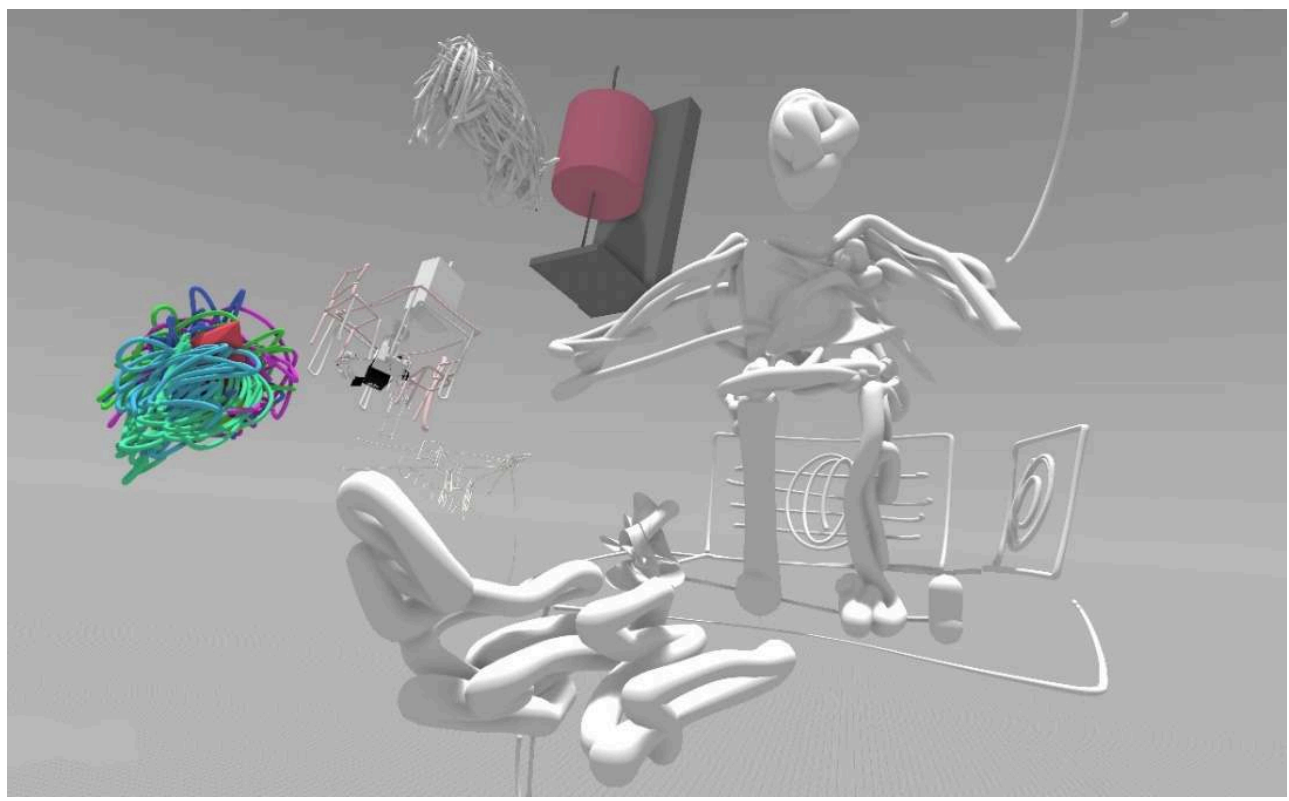

Dibujos virtuales generados durante la conferencia.

José D. Periñán, 2019.

\section{Acto 1. El cadáver de dios visto desde un Iphone}

La exposición Time and Umwelt se presentaba en ARCO 2018 dentro de más arte contemporáneo en Madrid, asociada a la sección El futuro no es lo que va a pasar, sino lo que vamos a hacer, como el primer recorrido expositivo en España de arte en Realidad Aumentada. Once obras virtuales de diez artistas fueron ubicadas en lugares específicos de la ciudad ${ }^{3}$, activándose mediante una aplicación que se descargaba gratuitamente. La exposición ocasionaba encuentros y desencuentros con las obras, enfoques polilógicos que se proponían abrir el pensamiento único hacia extrañas singularidades. Dos eran los conceptos que articulaban la exposición y que, aún hoy, continúan funcionando como fundamentos de ARAN, los cuales aparecerán desarrollados a lo largo de este texto : un tiempo policrónico, no lineal, asincrónico y alternativo a la Modernidad, y un Umwelt (mundo circundante) que alude a los diferentes hábitats animales, irreductibles al espacio homogéneo construido como ilusión de objetividad por el ser humano.

Fig. 2 Imágenes de las obras que integraban la exposición.
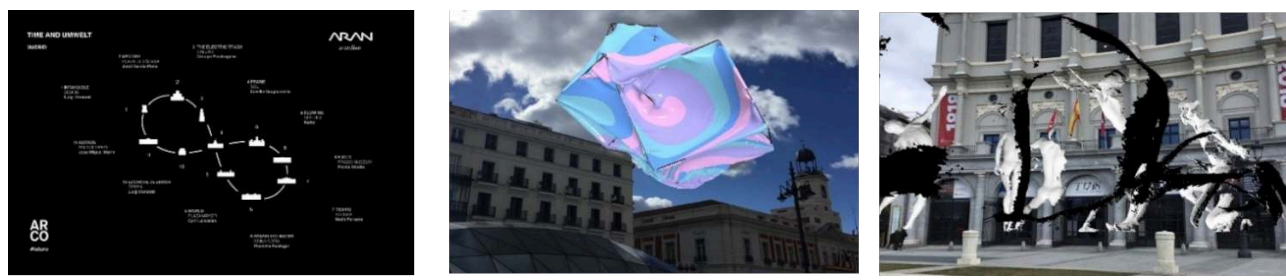

1. Plano de Time and Umwelt / 2. Frame, Catello Gragnaniello / 3. Écorchè \#5 Butoh, Luigi Honorat 

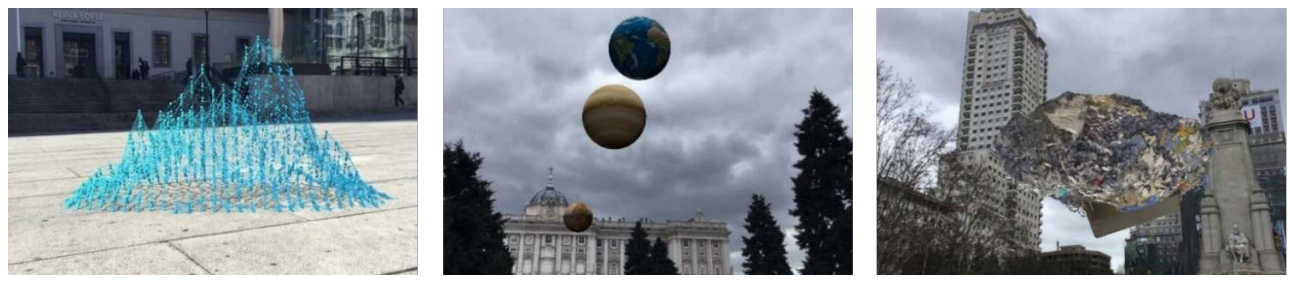

4. Sparkling water, Tamina Rastagar / 5. Astros, José Miguel Marín / 6. Memory, Jordi García Pons
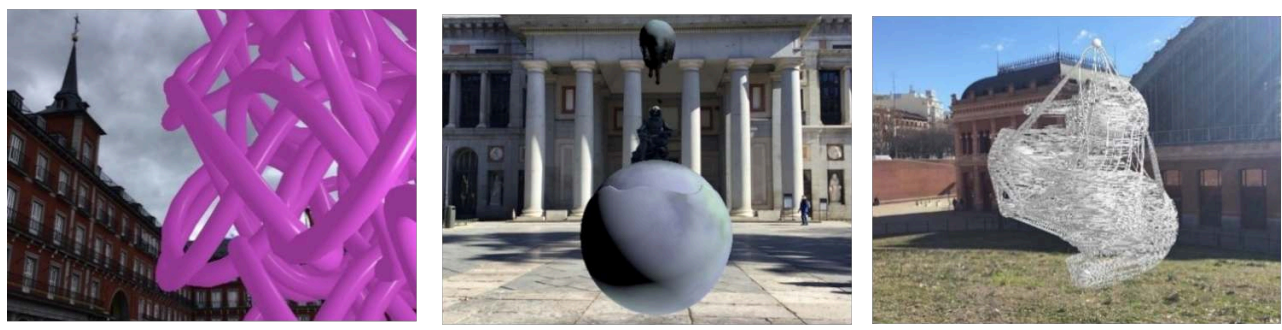

7. World, Cyril Lancelan / 8. EJDLD, Picota Studio / 9. Tiempo, Nadir Perazzo
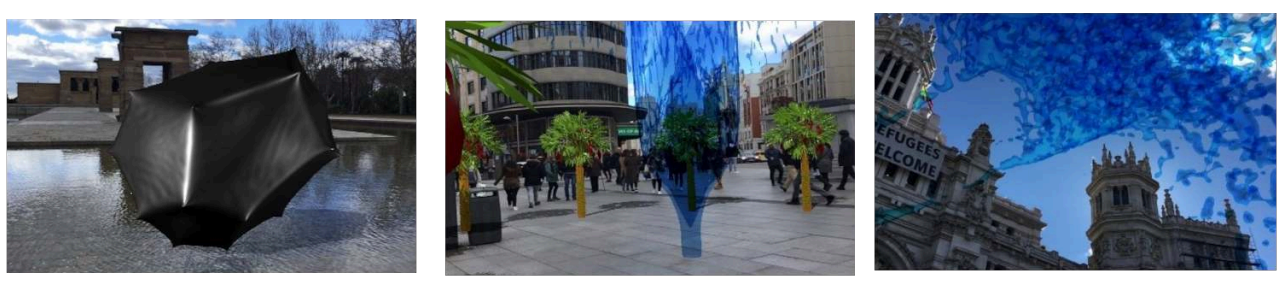

10. Intangible, Luigi Honorat / 11. The electric trash, Groupe Électrogène / 12. Flowing, Keltoi.

Time and Umwelt, 2018.

Bastaba pasear por Madrid y dirigirse a los puntos de geolocalización de las piezas para poder visualizarlas. Time and Umwelt fue, desde un punto vista curatorial, instalativa. En un radio de varios kilómetros, parte de la ciudad funcionó como una gigantesco parque para situar las obras virtuales. Siguiendo a Groys, suspendimos el espacio urbano convirtiéndolo en privado, otorgándole, de manera no perceptible, leyes propias ${ }^{4}$ que hacían de él un territorio de excepción ${ }^{5}$, para después reabrirlo como espacio "público" a través del acceso libre y gratuito a la aplicación. Revelábamos, así, que los territorios democratizados de los museos, espacios a los que todos los ciudadanos libres e iguales pueden acceder, poseen, al haber sido diseñados a partir de normas y criterios no consensuados, una huella violentamente dogmática. Pero, más allá de ello, ¿fue la liberación de nuestra macro-instalación, mediante el libre acceso a las piezas, auténticamente igualitaria? El espacio de excepción que construía Time and Umwelt no estaba al alcance de todos. Durante el desarrollo de la aplicación nos vimos obligados a distinguir entre los poseedores de la tecnología necesaria como requisito mínimo para visualizar las obras (a partir de un Iphone 6) y los que no lo eran. Trazamos, de un modo no querido, una clara línea que dividía a los espectadores. Los sujetos ya no quedaban definidos de un modo transcendente o metafísico, sino que se configuraban técnica, económica y políticamente. Existían los que podían ver, experimentar y hacer turismo con la Realidad Virtual ${ }^{6}$, privilegiados epistemológicamente por la tecnociencia, y los que no podían. Estuvimos obligados a cumplir con la exclusividad de las utopías históricas, esencialmente excluyentes, injustas, selectivas y no universales. Los usuarios que pudieron descargarse la aplicación fueron, a su modo, como el loco 
descrito por Nietzsche en el aforismo 125 de La Gaya ciencia, un visionario tecnológicamente equipado que puede ver lo que los otros no ven a través de su dispositivo móvil :

No habéis oído hablar de aquel hombre loco que en pleno día encendió una linterna,

fue corriendo a la plaza y gritó sin cesar: “¡Busco a Dios! ¡Busco a Dios!” [...]

“¿Dónde se ha ido Dios ?”, gritó. “¡Os lo voy a decir! ¡Lo hemos matado vosotros y

yo ! [... ¿ ¿No es preciso ahora encender linternas en pleno día ??

El poder visualizar las piezas en un lugar exclusivo como era la pantalla del Iphone redefinía, curatorialmente, el móvil como una linterna que se enciende en pleno día, y que sirve para ver el cadáver de Dios. Ahora bien : ¿cómo es que consideramos las piezas como objetos-cadáveres? ¿Qué suponía para nosotros, conceptualmente, el uso del teléfono móvil y qué operaciones producía en el territorio de la temporalidad?

\section{Acto 2. Los animales caminan en la ciudad: Umwelt y Iphones}

Pensemos en la película de Harun Farocki, Ojo máquina [Auge/Maschine] (2001), sobre la que reflexiona el director en los artículos Influencia cruzada / Montaje blando ${ }^{8}$ y La guerra siempre encuentra una salida9. En 1991, durante la Primera Guerra del Golfo, los Aliados situaron en la parte superior de los misiles cámaras que grababan en directo el movimiento del proyectil hasta el momento del impacto que se producía en el blanco. La cámara acababa destruyéndose, con la consiguiente interrupción de la imagen. Farocki las denomina "cámaras suicidas", cámaras que producen un nuevo tipo de imagen. Siguiendo a Farocki, Hito Steyerl en su libro Arte Duty Free interpreta que, en el momento del impacto, la cámara, en lugar de ser destruida, explota y se hace añicos, pasando de la unidad a la multiplicidad. El estallido de la cámara suicida deriva en innumerables pequeñas lentes que, desplazadas hasta nuestros teléfonos móviles, entran en la vida cotidiana de las personas ${ }^{10}$. La exposición de realidad aumentada Time and Umwelt, en la que las obras solo podían verse a través de los dispositivos móviles, recogía el arco interpretativo de Farocki-Steyerl, en una apuesta por la ruptura de la homogeneidad de los espacios, por la fragmentación de la unidad en una multiplicidad de usuarios como sujetos-perspectivas de recepción. 
Fig. 3 Hacerlo Explícito Cámaras suicidas de Farocki-Steyerl

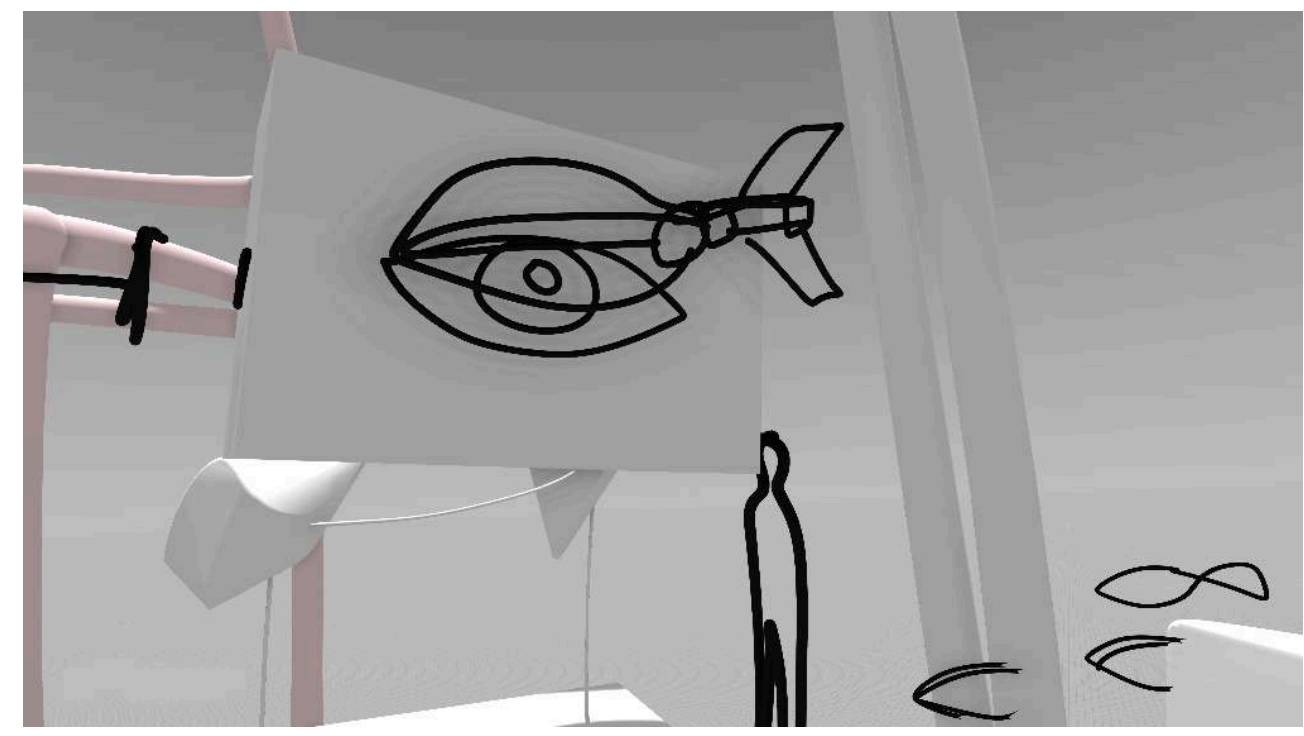

José D. Periñán, 2019

6 Cada espectador, cada activador de las piezas de la exposición, generaba un Umwelt, un mundo circundante, concepto acuñado por el filósofo y biólogo estonio-alemán Jacon von Uexküll en su libro Andanzas por los mundos circundantes de los animales y las plantas ${ }^{11}$. Según Uexküll, nos dejamos llevar fácilmente por la ilusión de que las relaciones que mantiene un sujeto extraño a nosotros con los objetos en su mundo circundante se juegan en el mismo espacio y en el mismo tiempo que las relaciones que nos unen con las cosas en nuestro mundo humano. Esta ilusión es alimentada por la creencia en la existencia de un único mundo omniabarcante en el que todos los seres vivos estarían empaquetados. De ello surge la convicción generalizada de que solo debería haber un espacio y un tiempo para todos los seres vivos. Frente al mundo objetivo, una construcción antropocéntrica que toma los objetos constitutivos de nuestra mundanidad como red homogénea (Umgebung), Uexküll afirma que no se puede garantizar que nuestro mundo circundante y el de los animales conste de los mismos objetos, pues cada animal está rodeado de una especie de burbuja que constituye su Umwelt. Siguiendo estas nociones, en ARAN concebimos a los usuarios de la exposición a partir del pensamiento de Uexküll y de manera semejante a la intervención de Pierre Huyghe titulada Umwelt (2011) ${ }^{12}$, en la que los visitantes humanos habitaban el espacio estando copresentes con arañas y hormigas, unos indiferentes para los otros, sin habitar el mismo mundo, sin compartir protocolos de exposición espaciales y temporales. Una indiferencia defendida por Vila-Matas o Chus Martínez como

principio positivo que apunta a un modo de coexistencia entre mundos, entre modalidades económicas, entre formas estéticas antagónicas basado en la no asimilación, en no asumir la continuidad del tiempo histórico ${ }^{13}$.

¿Creyeron los presentes en la sala donde tuvo lugar la conferencia que aquí y ahora transcribimos compartir mundo con nuestro Umwelt, mientras dibujábamos con las gafas VR las imágenes que se proyectaban? ¿Hasta dónde seguir con la ilusión de continuidad de los diálogos y de las comunidades únicas? ¿Cómo seguir aspirando hacia una integración cuando procedemos de un radical estar-con (Mitsein) desincronizado que se limita a explorar lo existente ? ${ }^{14}$ 
Fig. 4 Hacerlo Explícito, Umwelt y Iphones

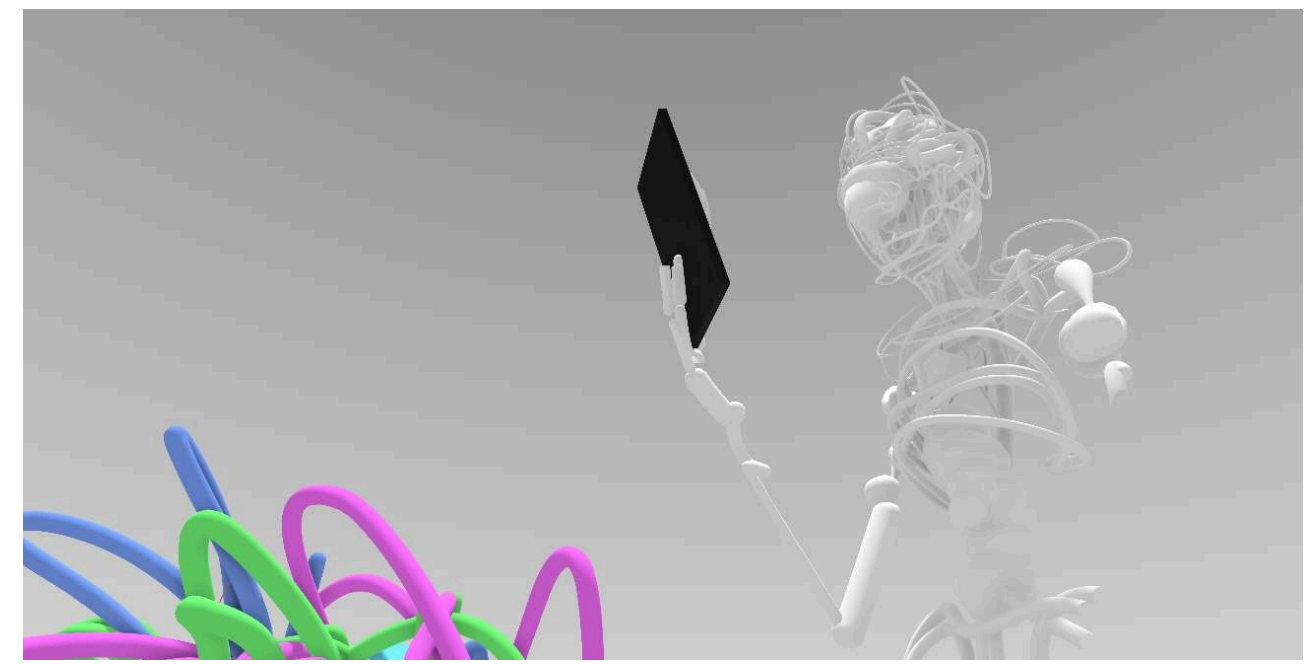

José D. Periñán, 2019.

Pensamos en los usuarios de los teléfonos móviles como seres que subvierten las síntesis y las unidades de los hábitos de mundanización. Cada usuario-espectador de Time and Umwelt, con su teléfono móvil, con su generador de mundo entorno, abría un abismo respecto a la sincronía del mundo objetivo. Siendo dueño de su espacio y de su tiempo y de diferencias que no pueden ser subsumidas, pasaba a ser ajeno a los tiempos de reunión establecidos por las máquinas institucionales del arte contemporáneo, hacedoras de presente y de presencia. Queríamos asegurar la heterogeneidad radical, fracturando los espacios homogéneos de visibilidad. Queríamos quebrar la seguridad del monótono-mundo y abrirlo a una multiplicidad semejante a la espuma pluralista de Sloterdijk ${ }^{15}$. Para nosotros, el uso del teléfono móvil equivalía a romper los acuarios que Huyghe mostró en Zoodram (2009-2013), destrozar la posibilidad de espacios compartidos, homogéneamente legibles, en los que se ha venido desplegando la Modernidad, sin recomponerlos en un museo y sin articularlos en un discurso curatorial estructurado. 
Fig. 5 Hacerlo Explícito, Pecera de Zoodram (Huyghe) y de El Séptimo Continente (Haneke)

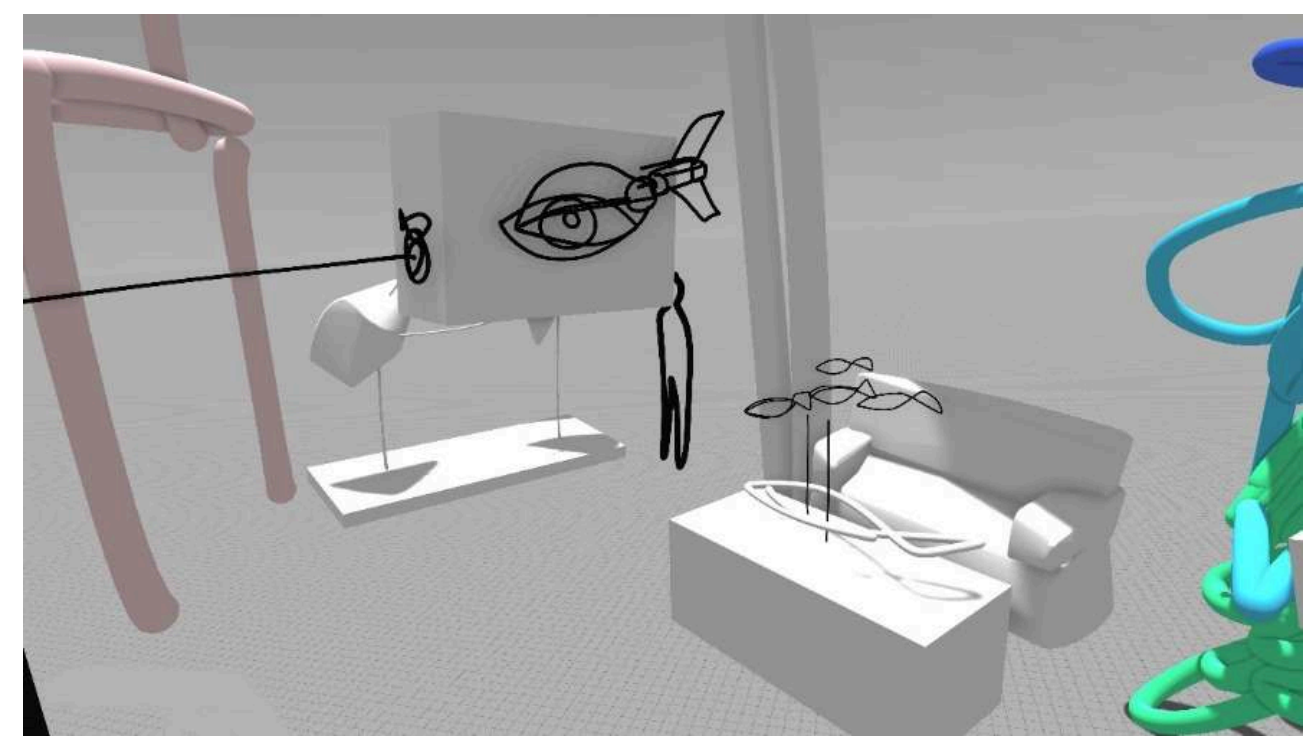

José D. Periñán, 2019.

9 Queríamos desvanecer la ficción de unidad que crea el arte contemporáneo ante una ausencia real de tiempos y espacios globales de la que habla Peter Osborne, fracturar el espacio común basado en una objetividad que no existe como tal ${ }^{16}$. De la buena voluntad y del optimismo de la Modernidad respecto a construir una unidadcomunidad para el diálogo cultural, queríamos hacer un espacio-basura, una radicalización del espacio-añico. Como sucede en una sobrecogedora escena de $E l$ séptimo continente de Michael Haneke (1989), en la que un martillo impacta contra un acuario, fracturándolo y haciendo que los peces salgan a otro Umwelt, queríamos romper con los discursos plurales que se aglutinan en la unidad. De algún modo, estábamos comisariando espacios fragmentados que ya no congregaban las obras en el lenguaje entendido como casa del ser, sino que presentaban una ruptura gramatical a martillazos, semejante a las "palabras en libertad" de Marinetti. Exponíamos las piezas como ítems individuales que, flotando en una nube anómala, ya no cuentan historias ${ }^{17}$.

\section{Acto 3. El martillo de Heidegger / Los objetos de Harman / El móvil y el mando de las gafas VR en ARAN}

10 El martillo de Haneke nos recuerda al martillo de Nietzsche que aparece en el Crepúsculo de los ídolos o Cómo se filosofa con el martillo ${ }^{18}$; también al martillo del que habla Heidegger en su análisis del útil en Ser y tiempo ${ }^{19}$, reinterpretado por Graham Harman en ToolBeing. Heidegger and the Metaphysics of Objects $^{20} \mathrm{y}$ en libros como Hacia el realismo especulativo ${ }^{21}$ o El objeto cuádruple. Una metafísica de las cosas después de Heidegger ${ }^{22}$. En Time and Umwelt la herramienta-martillo pasaba a ser para nosotros el teléfono móvil, del mismo modo que durante la conferencia que aquí transcribimos la herramientamartillo se transformaba en el mando de las gafas HTC Vive con las que generamos los dibujos virtuales que se proyectaban. Heidegger expone, en los parágrafos 15 y 16 del capítulo de Ser y tiempo titulado "La mundaneidad del mundo", nuestro modo originario de estar en el mundo, distinguiendo entre el ser-a-la-mano (Zuhandenheit) y el ser-ante- 
los-ojos (Vorhandenheit) ${ }^{23}$. En el ser-a-la-mano los útiles son lo inmediatamente accesible para el Dasein en su mero uso antes de cualquier tematización y presentación de las cosas, apareciendo de manera preteórica.

Fig. 6 Hacerlo explícito, El martillo de Heidegger / Los objetos de Harman / La tecnología en ARAN.

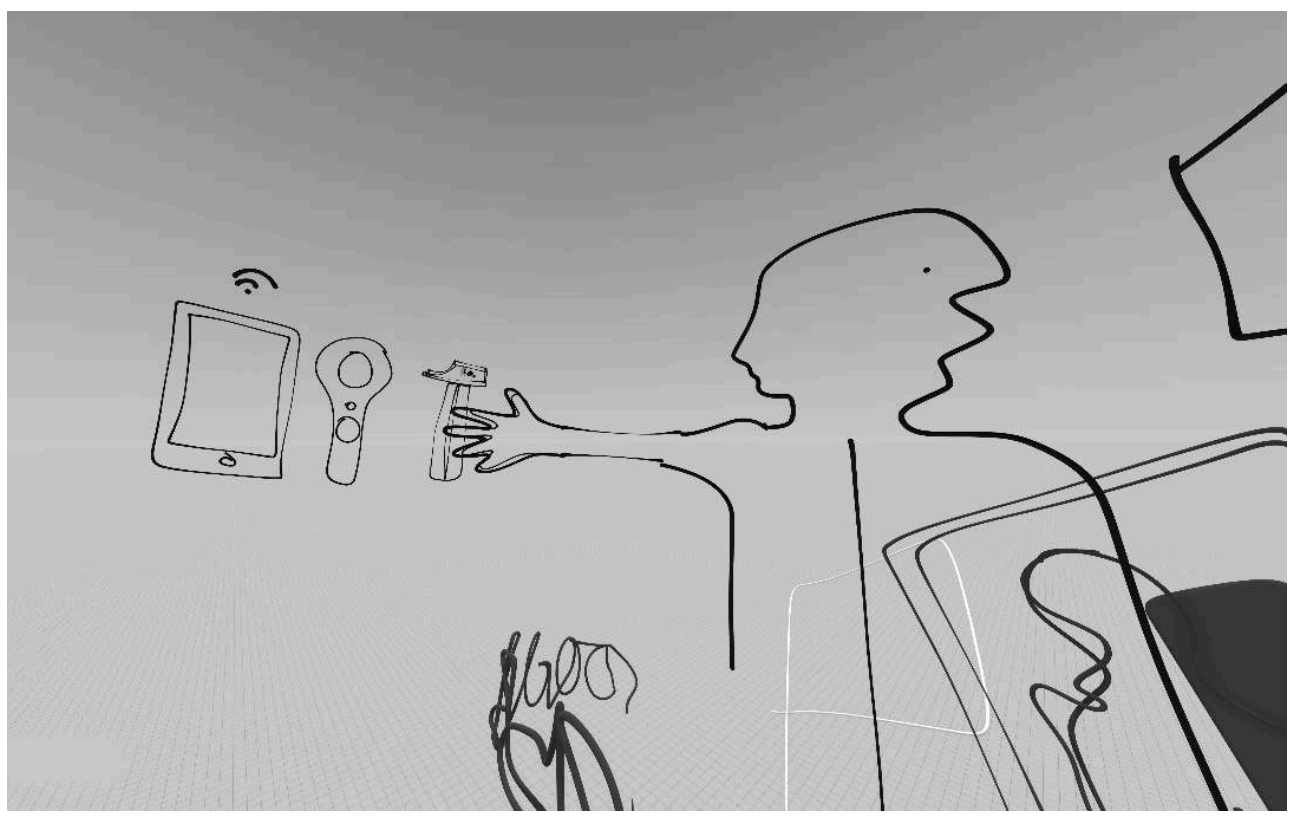

José D. Periñán, 2019.

Puesto que están siendo usados en el trasfondo no necesitan salir al discurso como serante-los-ojos. Pese a no aparecer bajo parámetros de observación especializada y científica, esta concepción heideggeriana de los objetos supone, para Harman, una carizaturización :

Después de todo, utilizar una cosa deforma su realidad no menos que elaborar teorías sobre ella. [...] nuestro uso del piso como un "útil para tenerse en pie" no entra en contacto con otras cualidades del mismo piso que solo los perros o los mosquitos serían capaces de detectar. En pocas palabras, tanto la teoría como la acción práctica son igualmente responsables de reducir las cosas a un mero estarahí. [...] Si contemplar un martillo no agota la totalidad de su ser, utilizarlo tampoco. [...] En la medida en que los útiles pertenecen a un sistema, ya desde un principio no son más que caricaturas de sí mismos, ya se encuentran reducidos al mero estar-ahí. [...] Si el ser de las cosas se encuentra velado detrás de la teoría y de la praxis, esto no obedece al mérito o al defecto del Dasein, sino al hecho de que todas las relaciones traducen y deforman aquello que relacionan, incluso cuando se trata de relaciones entre objetos inanimados ${ }^{24}$.

Heidegger es, aún, demasiado metafísico si consideramos el Dasein como eje vertebrador de nuestra experiencia del mundo. Frente al Heidegger y junto a Harman, nuestro uso de la herramienta no se circunsbribe a un modo de relación ni antropocéntrica ni metafísica. Más que sostener un martillo al modo heideggeriano, como si se tratara de una entidad menor que se adapta a la "conciencia", pensamos que " nuestros objetos en nuestras manos deben ser también iguales, también camaradas ", como escribe Alexander Rodchenko en una carta desde París en $1925^{25}$. Más que atender a una relación de aprehensión humana de los objetos, entramos en relaciones desincronizadas con los seres-a-la-mano. Entre el móvil, el mando y nosotros (entre 
nosotros y los oyentes de la conferencia ya referida) se producían prehensiones al modo de Whitehead, relaciones de objetos sin Dasein y sin mundo unificado, pues

no existe una sincronización previa de los objetos hecha por Dios ni por nadie ; más bien, las entidades tienen la libertad total de abrirse unas a otras, de llegar a los contactos mutuos más hipersensibles ${ }^{26}$.

13 Nos autoconcebimos en el manejo de la tecnología como podría concebirse una mosca sobre un teclado de ordenador, confrontando nuestro Umwelt con el Umwelt humanotecnológico. ¿No han acabado por convertirse las pantallas táctiles para casi todos nosotros en una superficie que, más que usar, acariciamos, como podría acariciar Lévinas las páginas de su libro Totalidad e infinito, sin saber por qué ? ${ }^{27}$

Para nosotros, el móvil y el mando VR quedan liberados de su caricaturización como útil que sirve para el ver o para el dibujar humanos, ya que se abren a otros objetos y a sus relaciones materiales. De concebirlos de algún modo, lo hacemos al margen de un enfoque sobre la tecnología pensada como metafísica cumplida en cuanto que sincronizadora de duraciones-mundos. El contacto de nuestras manos con el móvil, con el mando, o de nuestras cabezas y rostros con las gafas VR ha de verse, por tanto, en un tiempo no unificado. Su riqueza no engloba nuestra pseudo-mundanidad. Fuera de la puntualidad que sopondría el llegar a tiempo de nuestros cuerpos para su adaptación a la tecnología, nos desplazamos en la torpeza de su utilización. Igual que en las primeras vanguardias

la nueva tecnología fue interpretada [...] no como una posibilidad de construir un mundo nuevo y estable para el futuro, sino como una máquina que produce [...] la permanente destrucción de la civilización moderna y tecnológica ${ }^{28}$,

en ARAN concebimos lo tecnológico no como progreso que viene a salvaguardar la línea de la Modernidad, sino como desestructuración y partición de consensos espaciales y temporales.

\section{Acto 4. Tecno-provincianismo. La imagen no ergonómica}

16 Ni Time and Umwelt ni en la conferencia que transcribimos en este texto buscamos la creación de una plataforma para el sentido, sincronizando a los usuarios-oyentes (¿podemos seguir siendo útiles que se miran, se escuchan o se leen sin ser caricaturizados?) con discursos que se construyen como una sopa de letras a compartir por la koiné hermenéutica. Nos-otros, como los puntos de un dado que se lanza al azar ${ }^{29}$, fragmentamos los fenómenos, los separamos de su mero ser-para-nosotros. Nuestro Mitsein tecnológico se desconecta del presente, pues no tiene la pretensión de estar coordinado con el tiempo global. Podríamos afirmar que en ARAN nos vemos afectados por los dos modos de provincianismo que describe Greenberg : el de Kandinsky,

artista (generalmente de un país periférico) que con toda seriedad y admiración se consagra al estilo favorecido en el momento por el centro metropolitano, y que sin embargo falla en su intento de comprender de qué se trata dicho estilo ${ }^{30}$,

17 y el provincianismo de Cezánne, el del "artista, académico o no, que trabaja en un estilo pasado de moda o despreciado por el centro metropolitano" ${ }^{31}$. La relación entre nosotros y la tecnología global es la misma que la de los habitantes de Villar del Río con el plan Marshall aparecida en la película de Berlanga en $1953^{32}$. Podríamos hablar, en ARAN, de una tecnología periférica, sureña, provinciana, débil, del uso de los 
dispositivos móviles bajo unas condiciones climatológicas casi norteafricanas, más cerca como estamos de Marruecos que de Bruselas, Londres o Berlín, y por supuesto, muy lejos de nodos punteros tecnológicamente como Silicon Valley ${ }^{33}$, ignorando las posibilidades abiertas por las más recientes investigaciones en Realidad Aumentada, Virtual y Mixta. Tal vez nosotros seamos su pasado, pero, decididamente, ellas no son nuestro futuro. Por eso hemos de resolver nuestros tecno-problemas como si estuviéramos, cada vez, ante un abismo, donde la Modernidad no sirve ni siquiera para dar el primer paso. Los posibles enunciados de ARAN sobre el futuro, igual que los del futuro sobre ARAN, son enunciados "ancestrales" que tratan «sobre acontecimientos anteriores a la emergencia del hombre, [...] [y] sobre posibles acontecimientos ulteriores a la desaparición de la especie humana $\|^{34}$. En ellos el lenguaje abandona a las cosas donde las cosas solo pueden chocar entre sí. Es en este sentido en el que Time and Umwelt no mantuvo ninguna esperanza (como tampoco la mantuvo la conferenciaperformance paralela a este texto, donde los dibujos virtuales que se iban generando jamás coincidían puntualmente con el discurso) en el correlacionismo definido por Meillasoux, según el cual el mundo ha de ser un correlato, un siempre-ya, que se manifiesta para nosotros (en nuestro tiempo). Frente al correlacionismo de la Modernidad y de la hermenéutica, la ancestralidad

nos lleva a pensar un mundo sin pensamiento, un mundo sin donación de mundo. Estamos en la obligación, entonces, de romper con el requisito ontológico de los modernos según el cual ser es ser un correlato. Por el contrario, tenemos que intentar comprender cómo el pensamiento puede acceder a lo no-correlativo, a un mundo capaz de subsistir sin estar dado. Ahora bien, decir esto es decir también que debemos comprender cómo el pensamiento puede acceder a un absoluto: a un ser también desligado (sentido primero de absolutus), también separado del pensamiento, que se nos ofrece como no relativo a nosotros, como capaz de existir más allá de que nosotros existamos o no ${ }^{35}$.

18 Nuestra torpe aproximación a la tecnología, para la que siempre llegábamos impuntuales y a destiempo, nos apartaba del correlacionismo para adentrarnos en abismales relaciones de ancestralidad. Incurríamos, por tanto, en el anacronismo que supone la producción de una exposición de Realidad Aumentada casi en el seno de la nada $^{36}$. Debido a una incipiente experimentación con la Realidad Virtual, en Time and Umwelt se generaban errores en el comportamiento del software. La correcta aparición de las piezas solo se producía en contadas ocasiones. Más que atender a la perfecta visibilidad de las obras, creamos una exposición activamente anti-ergonómica. Frente a la operación de sincronización puesta en marcha por las cámaras de los móviles, hoy regidas por patrones de fotografía postdigital y computacional donde los algoritmos recomponen la imagen limpiando el ruido o los restos inservibles que puedan obstaculizar su aparición confortable ${ }^{37}$, la precariedad de los soportes digitales hacían que en la exposición estas operaciones algorítmicas pareciesen demasiado humanas. Contra el algoritmo, contra su teocracia computacional de la que habla Ian Bogost ${ }^{38}$, contra su mitología, contra sus imposiciones de optimización, contra su design postmetafísico, contra su construcción de mundo basada en la correlación y en el mantenimiento del consenso, Time and Umwelt dejaba surgir el glitch ${ }^{39}$. Esperaba la caída del tiempo, la aceptaba, permitiendo la autonomía de una ontología orientada a objetos (000) que interactuaban entre sí, también caricaturizándose, pero esta vez sin el predominio de lo humano ${ }^{40}$. 
Fig.7 Hacerlo explícito, Prehensiones y contactos entre objetos desincronizados

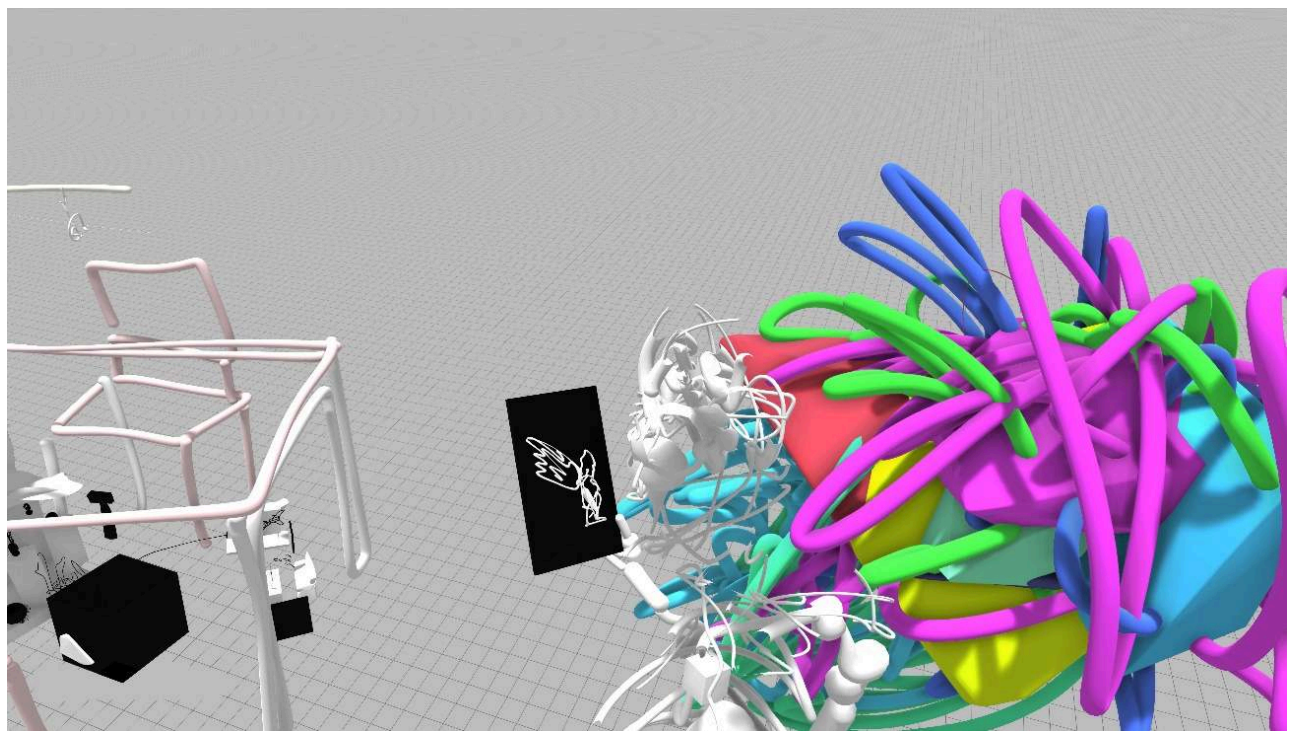

José D. Periñán, 2019.

\section{Acto 5. Giros en $\mathrm{U}$ : el mundo como ready-made}

El estallido de los espacios unitarios en Time and Umwelt, así como la aceptación de la asincronía, conlleva practicar una dislocación en el concepto lineal del tiempo moderno y progresivo, un movimiento de retracción, un paso atrás (Schritt zurück) ${ }^{41}$ respecto a la superación (Aufhebung) metafísico-moderna. Siguiendo a Groys, supone ejecutar un giro en $\mathrm{U}$ o metanoia, un dar la vuelta a la mirada como Giuseppe Penone en Rovesciare y propri occhi (1970). En ARAN apostamos por este mirar atrás no metafísico que disuelve el tiempo de la línea. Cuando resulta imposible continuar, ya sea porque la historia ha terminado (Hegel), porque se ha llegado al límite de las propia fuerzas (Nietzsche), a la posibilidad de cumplir el deseo (Freud) o al extremo de la existencia (Heidegger), es posible mirar atrás, como señala Groys, igual que lo hace el Angelus Novus de Klee, a partir de la desfuncionalización del status quo operada por las vanguardias ${ }^{42}$. 
Fig. 8 Hacerlo Explícito, Virtualización del mirar atrás. Giro en U - Metanoia

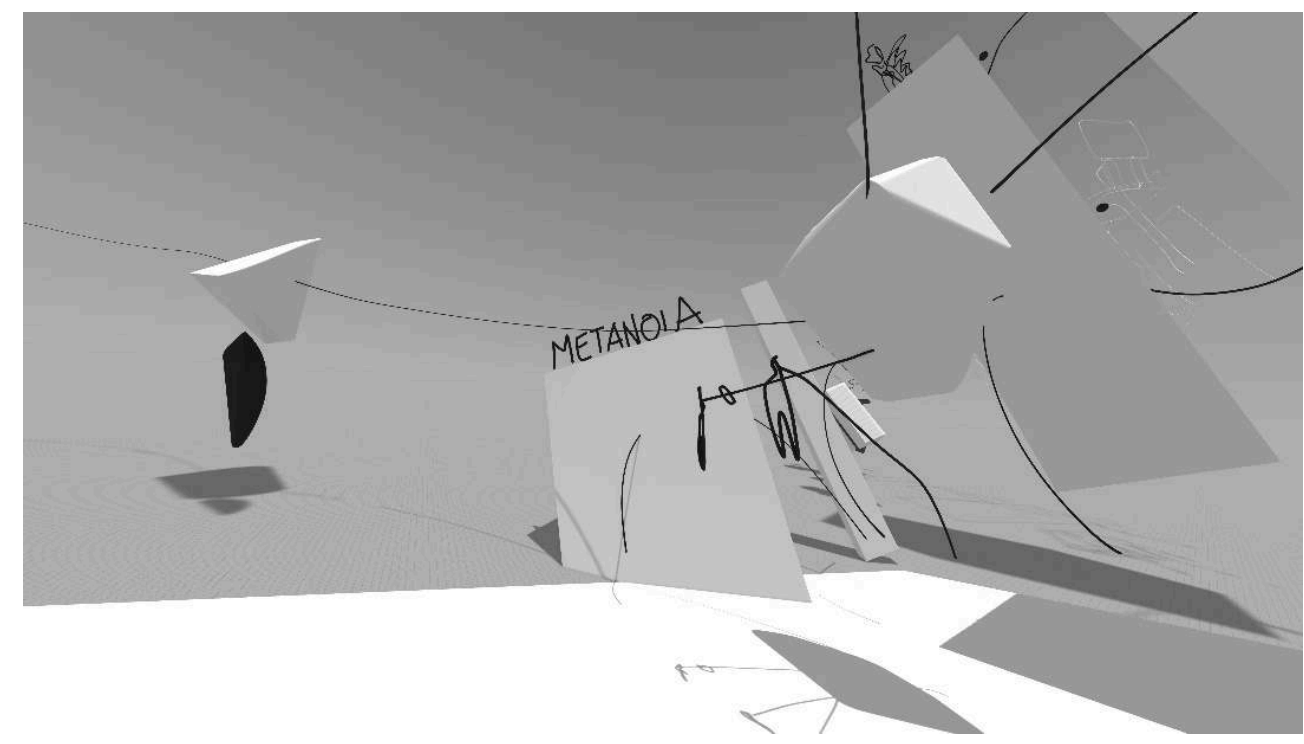

José D. Periñán, 2019.

Pero, ¿dónde reside, en concreto, nuestro arte de darse la vuelta? Tras la muerte de Dios, cuando no es posible continuar diseñando el alma en el teatro de un espectador trascedente, es necesaria una autopoética liberadora. Salir de la Modernidad y de la metafísica supone escapar al diseño, pues, «donde alguna vez estuvo la religión, ahí emergió el diseño. El sujeto moderno tenía ahora una nueva obligación: la del autodiseño, la presentación estética del sujeto ético ${ }^{43}$. Para escapar a las secularizaciones de la Modernidad, Groys distingue entre el diseño y el arte :

la estetización artística es lo opuesto a la estetización por medio del diseño. El objetivo del diseño es mejorar estéticamente el status quo, hacerlo más atractivo. El arte también acepta el status quo, pero lo acepta como un cadáver, en tanto lo transforma en mera representación. En este sentido, el arte ve la contemporaneidad desde la perspectiva no solo revolucionaria, sino también posrevolucionaria. Podríamos decir que el arte moderno o contemporáneo ve la modernidad o la contemporaneidad como los revolucionarios franceses vieron el diseño del Antiguo Régimen : obsoleto, reductible a una pura forma, un cadáver. [...] El arte acepta el status quo en tanto disfuncional, fallido ${ }^{44}$.

Contra el diseño, Time and Umwelt planteaba la estetización artística a través de la interactuación con nuestros teléfonos móviles. Mirando a través de ellos, el mundo, el presente, aparecía como un ready-made desfuncionalizado, pues las condiciones técnicas que hacían posible la visibilidad de la imagen desfamiliarizaban la existencia del status quo. Como el loco con la linterna de La Gaya ciencia, el usuario giraba su mirada ante el progreso al activar la obra virtual, pudiendo ver las cosas como el cadáver de Dios convertido en resto material y detrito de la historia. Tal vez lo decisivo para producir el giro metanoico en Time and Umwelt fuera la inclusión de la fotografía como una opción dentro de la propia aplicación, la cual permitía realizar una instantánea de las piezas virtuales. Pensado desde un punto de vista curatorial aplicado a un espacio físico, este gesto equivaldría a distribuir entre todos los visitantes de un museo una cámara de fotos como premisa constitutiva de la experiencia estética, obligándoles, más que a contemplar o a recibir las obras, a producirlas a través de la pantalla y a tomarlas como potenciales. 
Fig. 9 Hacerlo Explícito, Producir la imagen / marco de visibilidad

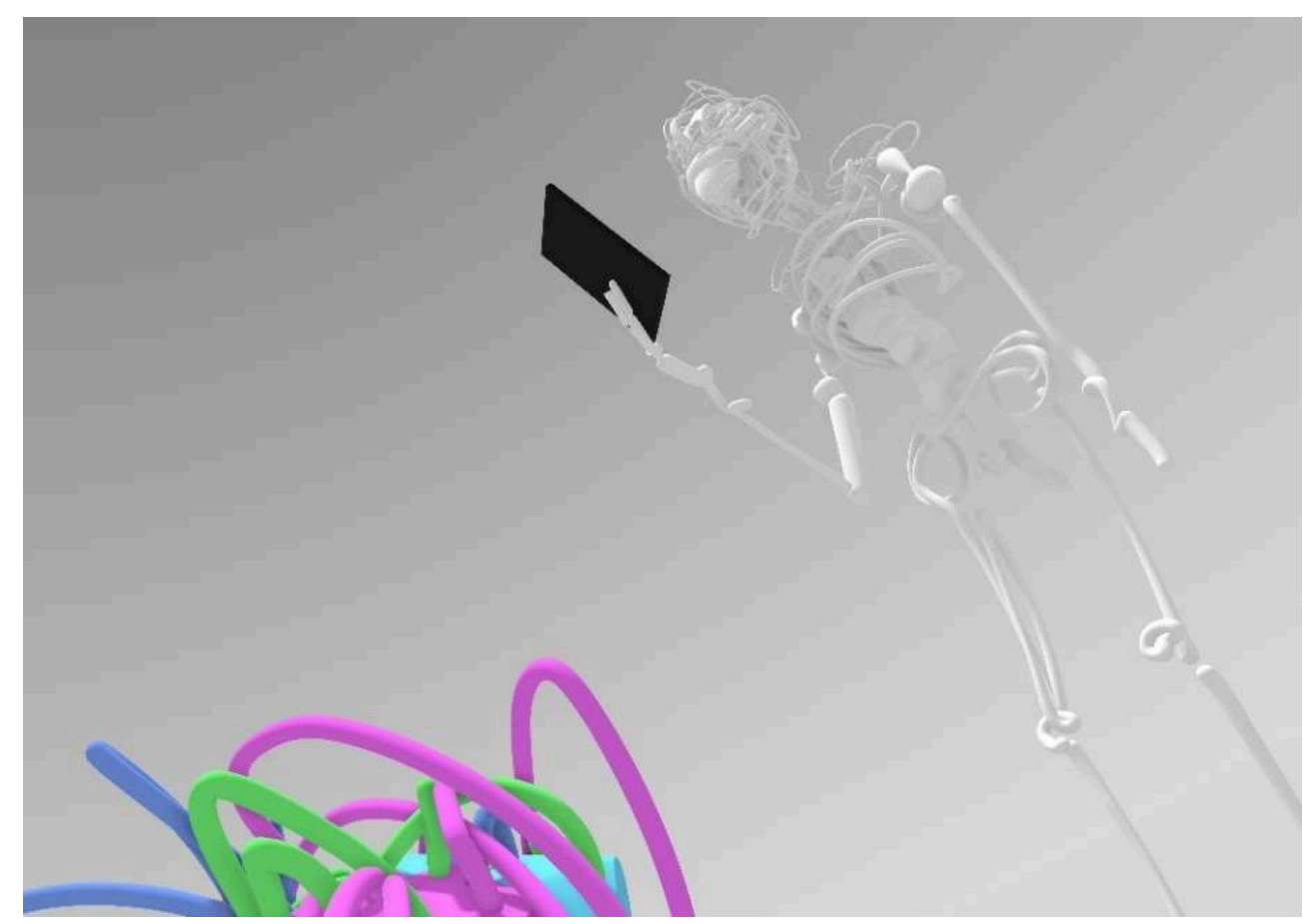

José D. Periñán, 2019.

Era nuestro modo de explicitar el hardware, el teléfono móvil como indicio de la disfuncionalidad total del mundo. Siguiendo a Groys, frente al usuario típico de internet que pasa por alto el hardware, queríamos evidenciar el marco objetual de la aparición de las imágenes, del mismo modo que Bertold Bretch rompió con la ilusión teatral, como el constructivismo ruso produjo objetos físicos o como Marinetti transformó el texto en cosa. Producir la imagen, autocrear la ficción, pasaba necesariamente por sujetar el marco del teléfono, haciendo que lo observado se desfuncionalizase ${ }^{45}$. Podía verse a los usuarios deviniendo cuerpos alienados que realizan el mero trabajo físico de sostener, como los trabajadores de Santiago Sierra en la intervención Forma de $600 \times 57 \times 52 \mathrm{~cm}$ construida para ser mantenida perpendicular a una pared (2001), o como sucede en la performance de Marina Abramović The Artist is Present, celebrada en el atrio del MoMa en 2010, donde la artista presentaba el esfuerzo físico de estar presente durante el horario de apertura al público ante los asistentes que la visitaban ${ }^{46}$. 
Fig. 10 Hacerlo Explícito, Virtualización de la muerte de dios y de la metanoia operada por el Angelus Novus de Klee.

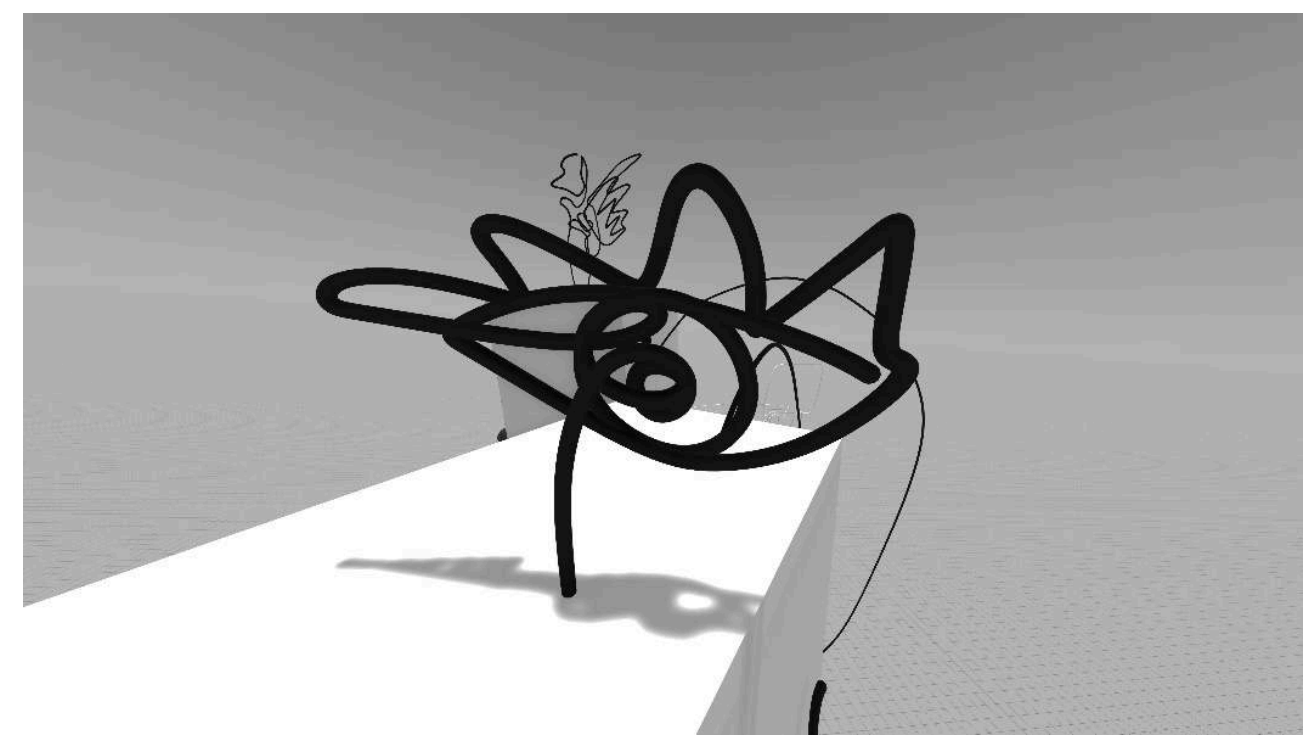

José D. Periñán, 2019. dispositivos públicamente. Como sucede cuando vemos una famosa escena de La Jetée (1962) de Chris Marker, donde aparece un personaje conectado a unos sensores que cubren sus ojos y que sirven para producir una ficción, o como sucede en las Museum Photographs de Tomas Struth, donde observamos a gente mirando a personas que miran cuadros, en Time and Umwelt nos convertíamos en contempladores que ven a otros contempladores. Mirando a través de la cámara del móvil, las personas podían aparecer inesperadamente, interfiriendo en el campo de visión y en la percepción de la pieza ${ }^{47}$. Ello las hacía "reflexionar sobre sus propias condiciones [...], exhibirse ellas mismas para sí mismas"48. A esta desfuncionalización contribuía que los usuarios pudieran realizar selfies con las piezas virtuales y compartirlas en las redes sociales, testimoniando ante los demás que, como privilegiados tecnológico-estéticos, podían ver, a la luz del día, el cadáver de Dios. Tal vez ellos mismos fueran este cadáver : el selfie, consecuencia casi natural de la interactuación con las obras, convertía a los usuarios en un Angelus Novus, en ángeles del final de la historia que constatan que el mundo ha devenido cadáver, y que ellos mismos son un objeto susceptible de desfuncionalización, sirviendo como material para auto-realización de un ready-made. Con el futuro a su espalda, los usuarios de Time and Umwelt estaban dando la vuelta al mundo del progreso y construyendo autopoéticamente su imagen como artistas.

\section{Acto 5. Kénosis / Vaciamientos : en defensa de la imagen pobre}

La interiorización de la línea como estructura articuladora del ser (ser = un modo de pronunciar una totalidad derivada de lo intotalizable) quedaba en Time and Umwelt desvirtuada. Y ello, siguiendo de nuevo a Groys, a través de lo que él llama la metanoia vertical ${ }^{49}$. Las imágenes de Time and Umwelt (también las generadas en la conferenciaperformance ya referida) se oponían al camino lineal que supone el arte entendido 
como vía ascendente de elevación, perfección o mejoramiento. Desde el punto de vista cutatorial y artístico, hallan su fudamento (desfundamentado) en la kénosis de la tradición cristiana, concepto que interpretamos también desde Vattimo ${ }^{50}$. Son debilitantes, vaciadoras, disolventes, pues no buscábamos crear algo más nuevo ni mejor. Más que una dinámica hacia un arte definido como mejoramiento de lo existente producido y de lo existente productor, lo que corresponde al ámbito del diseño que amplía y continúa el status quo de lo comtemporáneo, ARAN prefiere producir contradiseños radicalmente peores, crear imágenes pobres y defenderlas como inspiradoras al otorgarles la palabra.

Fig. 11 Hacerlo Explícito, Imágenes pobres, débiles, kenóticas

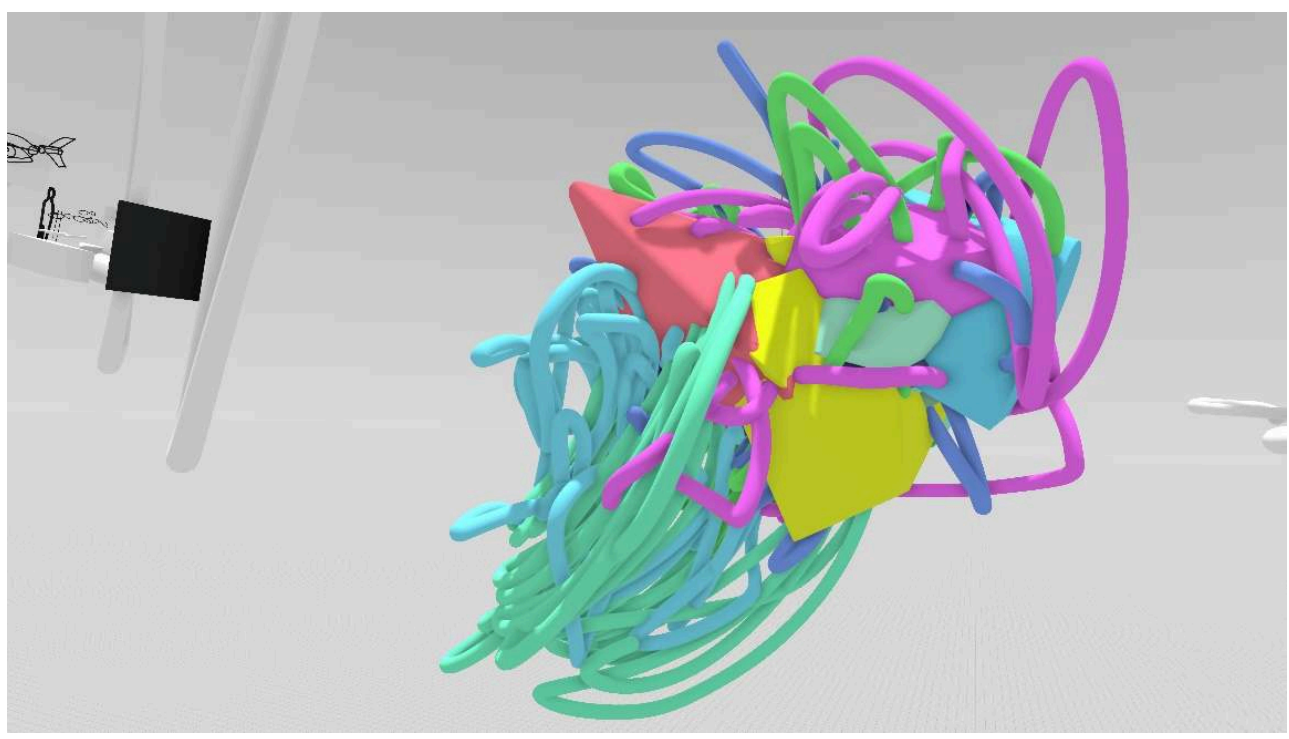

José D. Periñán, 2019.

Estamos de acuerdo con la dialéctica de la imperfección que despliega Malevich en el texto "Dios no ha sido destronado" (1919), según el cual deshacerse de la idea de mejoramiento no es posible si continuamos siendo ingenieros o sacerdotes que buscan la perfección ${ }^{51}$. ¿Qué es el cuidado (Sorge) heideggeriano sino un despliegue intrametafísico que cultiva el mejoramiento en el gimnasio de la nada y la autenticidad ? Fuera del cuidado, en el descuido del que nos habla François Jullien ${ }^{52}$, los artistas están en disposición de desembarazarse de los diseños antropotécnicos como santidad secularizada, pues aceptan su finitud como fracaso radical. Como escribe Groys :

La visión materialista del mundo abre una zona más allá del éxito y del fracaso, de la conservación y la aniquilación, de la adquisición y de la pérdida. [...] Pero entonces, si somos mortales y finitos, ¿cómo podemos cambiar el mundo ? Como ya he sugerido, el criterio para el éxito y el fracaso es justamente lo que define el mundo en su totalidad. Por eso, si cambiamos -o incluso mejor, abolimos- estos criterios, estaremos, de hecho, cambiando el mundo en su totalidad. Y como he tratado de mostrar, el arte puede hacerlo. Es más : ya lo ha hecho. [...] A partir de la época de las vanguardias, el arte se volvió no solo un objeto de discusión libre de todo criterio de verdad, sino también una actividad universal, no productiva y libre de todo criterio de éxito ${ }^{53}$. desde el diseño, es posible crear y exponer imágenes pobres, reducidas, débiles, igual 
que los artistas de vanguardia crearon imágenes "tan pobres, tan vacías que podían sobrevivir a cualquier posible catástrofe histórica" ${ }^{54}$, al giro de la historia y al impacto de la inercia de la cadena injustificada de acontecimientos, victorias y pérdidas. El futuro vacío solo puede aceptar la ligereza de la imperfección ; en él no caben, nunca lo han hecho, el background de los logros, progresos, expansiones o continuidades humanas ${ }^{55}$. Recordamos la sección Futuro de ARCO 2018. Comisariada por Chus Martínez, Rosa Lleó y Elise Lammer, fue definida como una sección "tranquila", tal vez desilusionante, pero

capaz de señalar la continuada validez de un lenguaje, el artístico, que se desarrolla sin intentar ejemplarizar, sin ningún tipo de altanería, sino con la esperanza de sobrepasar la experiencia del mero evento y contribuir a crear una forma de discernir distinta ${ }^{56}$.

En ella se producía, tácitamente, una metanoia vertical o kénosis en la aceptación de la imagen pobre, como escribe Steryerl, "enigmática e inconclusa por el descuido o el rechazo político, por la falta de tecnología o financiamiento"57. De ahí que defendamos imágenes tecnológicas no ascensionales, similares a los oggeti in meno de Pistoletto, que traicionen las expectativas, que acepten los titubeos y las imperfecciones. Tal vez supone, frente al sacrificio de la santidad y su antropotécnica secularizada, un movimiento contra-moderno que carece de sentido, un sacrificio estético que se realiza sin consecuencias y que anula la voluntad de triunfo basado en las variantes de la corrección y en el éxito del reconocimiento consensuado ${ }^{58}$. "Puede hacerse mejor" : en esta frase, el enlace entre "poder" y "mejor" podría definir un capítulo paradigmático de la racionalidad moderna. La ausencia de responsabilidad histórica (una bio-grafía es también una historia de los vencedores) permite sacrificar el mejoramiento, el diseño, en un arte kenótico que salva del progreso y de las aspiraciones ascendentes, del «alpinismo artístico, social y político (...), [ un arte que] no desarrolla el "potencial humano", sino que lo anula, [que] no opera por expansión, sino por reducción $»^{59}$ y que no pretende capitalizar el talento humano.

Solo de este modo escaparemos de la presión de nuestros dones y talentos, los que nos esclavizan y agotan hasta empujarnos a escalar una montaña tras otra. Solo si aprendemos a estetizar tanto la falta de dones como el hecho de poseerlos $\mathrm{y}$, por lo tanto, solo si no diferenciamos entre el éxito y el fracaso podremos escapar al bloque teórico que amenaza al activismo en el arte contemporáneo ${ }^{60}$.

\section{Acto 6. Imágenes-kebab}

Nuestras imágenes quieren ser una historia contada por un idiota que nada significa, alterar la lógica sincronizadora del mundo que las rodea ${ }^{61}$. Consideradas, tal vez, como correos no deseados, como mensajes sin contenido, son contra-hermenéuticas ${ }^{62}$, basura comunicativa e idiótica vista por el ángel de la historia. Funcionan, de algún modo, como el spam al que se refiere Hito Steyerl en el ensayo Desechos digitales (2011). En él analiza el surgimiento del spam en los años ochenta, cuando, independientemente de su contenido, fue usado como bloque material, como un volumen extensivo e invasivo que servía para expulsar de la pantalla de manera irritante a otros participantes en los foros multiusuario $0^{63}$. Es este el sentido que le otorgamos a nuestras imágenes. Si los spam digitales que recibimos a diario prometen escenarios de mejoramiento y optimización de la vida, incrementando el status quo, en ARAN los abordamos como un modo de captar el ruido sin destinatario, como una manera de sostener la llegada de los 
restos insignificantes, como choques contra-modernos. Aceptamos el fracaso de las imágenes pobres e insignificantes como ruido de los débiles, de los desechos de la Modernidad, de lo que, según Vattimo, fue para el segundo Heidegger el ser, para Derrida los márgenes de la filosofía o para Benjamin la historia de los vencidos ${ }^{64}$. Un ruido semejante al ruido del que habla Jacques Rancière ${ }^{65}$, al sonido de los extranjeros, los esclavos, las mujeres y los niños emitidos en la polis griega, inexistente en cuanto a sujetividad política frente a los enunciados de los ciudadanos acaudalados, privilegiados como información a tener en cuenta. Imágenes como sonidos confusos de un espacio doméstico donde no se articulan informaciones claras, formalizables, relevantes ni susceptibles de sincronización y que, según Steyerl, funcionan "como un tipo de filtro de spam político [...] [considerándose como] molestias irrelevantes, irracionales y potencialmente peligrosas" ${ }^{\prime 6}$. Nuestras imágenes débiles, nuestros ruidos visuales casi ininteligibles, entran en el futuro del modo más ligero y despreocupado porque están fuera de la historia. Son casi sonidos de un idiota virtualizado, aminoramientos hermenéuticos sobre los que no se puede construir consenso, continuidad ni prevalencia. En su su escapada del lenguaje, más que relacionarse con las palabras o con un discurso a interpretar, nuestras imágenes aparecen como objetos. Como escribe Steyerl,

antes de que la palabra spam se volviera una palabra que se transformó en un objeto, ya era un objeto [...] : la famosa lata de carne enlatada producida por Hormel Foods Corporation. [...] El spam era, y todavía es, un alimento básico para las clases populares y el ejército. (...) Pero el spam no existe sin su contrapoder. En la admirable pintura Actual Size [Tamaño real] (1962), de Ed Ruscha, una lata resplandeciente de Spam es captada en una trayectoria decendente. Su cola luminosa le hace verse como un cruce entre un cometa y una bomba molotov. El spam es un objeto sólido, aéreo y combustible, potencialmente imbuido de poder cinético. Las latas de spam pueden ser arrojadas contra las vidrieras de los bancos. Son fuertes y resistentes ${ }^{67}$.

La carne de baja calidad consumida por las clases populares, inauténtica, modesta y de bajo coste que aparece en Ed Ruscha y en Steryerl es procesada por ARAN e introducida tecnológicamente en espacios virtuales como objetos extra-lingüísticos, no correlacionales, revolucionarios, abiertos a un realismo no dogmático contra-ilustrado y contra-domesticado por el Dasein. En lugar de imaginar a Heidegger leyendo este texto y privilegiando, tácitamente, nuestro mensaje como hacedor o continuador de un mundo sincronizable, podríamos imaginarlo consumiendo la carne de nuestras imágenes-kebab, realizando el acto biológico de deglutir en una casa del ser convertida en un pequeño establecimiento de comida, metabolizado un tiempo exterior al Dasein, al lenguaje y "sus caminos", despertando en un nuevo e inédito claro (Lichtung) tal vez pobre de mundo, en una granja que se rompe en pedazos donde solo alcanzara a decir descuidadamente, en su Umwelt desincronizado, la respuesta a la pregunta por el ser que dejó sin responder en Ser y tiempo, proclamando la caricatura poética y espaciadora de un lenguaje, al fin, no temporalmente metafísico : “joing oing !”. 
Fig. 12 Hacerlo Explícito, Imagen-kebab / conferencia-kebab.

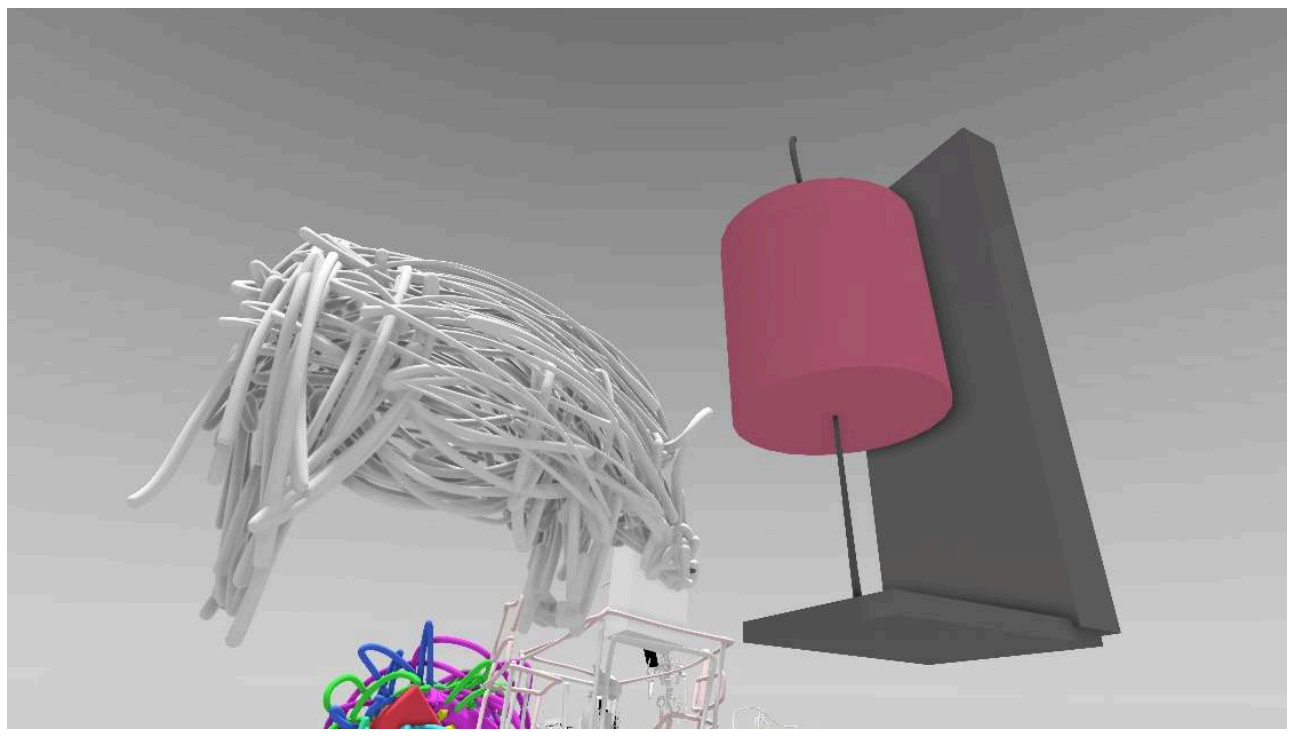

José D. Periñán, 2019.

\section{Epílogo : instrucciones para deshacerse del texto}

¿Qué queda, entonces, por hacer, cuando los animales se han decidido a caminar por la ciudad para coexistir con el Umwelt humano? En Time and Umwelt y en la conferencia aquí recogida queríamos explicitar la emergencia de múltiples mundos que escapan al Uno-Todo. Pero, ¿acaso no es este texto una nueva superficie de sincronización y unidad en la que el lector quiere llegar a la puntualidad del sentido que, en él, está aconteciendo? Considerar este artículo desde la reunión heideggeriana supondría reducir la multiplicidad desplegada por ARAN en sus intervenciones. Y es que, desde el punto de vista de las culturales prehensiones humanas, este escrito no es sino una caricaturización más de la complejidad radical por la que apostamos en nuestras prácticas artísticas y curatoriales. ¿No deberíamos, por tanto, repensar sus posibilidades y sus límites hasta lograr deshacernos de todo reduccionismo hermenéutico, de todo correlato respecto a un mundo que solo puede y quiere ser experimentado exclusivamente para nosotros? Quizá, como indicaba Wittgenstein en la proposición 6.54 del Tractatus ${ }^{68}$, tendríamos que arrojar la escalera del lenguaje una vez que nos hayamos encaramado en ella, no porque hayamos llegado al silencio indiscutible de aquello de lo que no se puede hablar, sino para adentrarnos en la complejidad y en el azar de los sonidos no lingüísticos emitidos por la escalera al caer. Steyerl teorizaba sobre el spam haciendo del lenguaje-basura un objeto concreto. Quizá, siguiendo su pensamiento desde un punto de vista especulativo, podríamos comenzar a pensar que el papel o la pantalla sobre el que este texto está impreso o presentado visualmente habla sin lenguaje, por sí mismo, que conversa en un idioma que ignoramos con los dedos de las manos que lo sostienen, con el aire que lo circunda y con las partículas de luz que lo hacen visible. Si entrara en contacto con el agua de los acuarios de Huyghe, su tinta se disolvería, haciendo de nuestros diccionarios plantas o animales acuáticos que duermen en el fondo del océano, junto a la delicadeza de las algas, con la suavidad de las esponjas, en tiempos diferentes a las duraciones meramente humanas. Para los animales, siempre desconocidos, no existe el constante 
compromiso de leer. Para nosotros tampoco. Tal vez haya llegado la hora de descubrir, en ello, un encantamiento ${ }^{69}$.

\section{NOTAS}

1. PÁGINA WEB DE ARAN (2018), «Time and Umwelt », [disponible el 11/12/2019] <URL: https:// aran.live>.

2. En la producción de la exposición participaron Eva Aro (Nemaniax) y Antonio Puentes (desarrolladores informáticos), así como Maite Coloma (cofundadora de ARAN junto a José Delgado).

3. Las geolocalizaciones se distribuyeron en los siguientes puntos: Templo de Debod, Edificio España, Plaza de Callao, Puerta del Sol, Plaza Mayor, Plaza del Museo Reina Sofía, Estación de Atocha, Museo del Prado, Plaza de Cibeles, Teatro Real y Palacio Real de Madrid.

4. Boris GROYs, Arte en flujo. Ensayos sobre la evanescencia del presente, Buenos Aires, Caja Negra, 2016, p. 101-102.

5. Giorgio AGAMBEN, «¿Qué es un campo?", Artefacto. Pensamientos sobre la técnica, 2, Buenos Aires, 1988, p. 52-55. Sobre esta idea puede consultarse el libro de David MORIENTE, Poéticas arquitectónicas en el arte contemporáneo, Madrid, Cátedra, 2010, p. 258-259.

6. Boris GROYS y Vittorio HöSLE, La razón al poder. Una discusión, Valencia, Pre-Textos, 2014, p. 73-79.

7. Friedrich NIETZSCHE, La gaya ciencia, Madrid, Ediciones Akal, 2001, p. 160-161.

8. Harun FAROCKI, Desconfiar de las imágenes, Buenos Aires, Caja Negra, 2015, p. 118.

9. "Estas imágenes de una cámara arrojándose sobre un objetivo, es decir, de una cámara suicida, se han grabado en nuestra memoria. Se trataba de algo nuevo [...]. En 1991 se habló mucho del hecho de que las imágenes de las cámaras que vigilaban la aproximación al blanco y la explosión mostraban la guerra 'como un juego de computadora"'. Ibid., 2015, p. 147-150.

10. Hito STEYERL, Arte duty free. El arte en la era de la guerra civil planetaria, Buenos Aires, Caja Negra, 2018, p. 95.

11. Jakov von UEXKÜLL, Andanzas por los mundos circundantes de los animales y los hombres, Buenos Aires, Cactus, 2016.

12. Emma LAVIGne (dir.), Pierre Huyghe. Catalogue de l'exposition, Paris, Centre Pompidou, galerie Sud, 25 septembre 2013-6 janvier 2014, Paris, Éd. du Centre Pompidou, 2013, p. 184.

13. Chus MARTíNEZ, Idiosincrasia. Las anchoas sueñan con panteón de aceituna, Cáceres, Centro de Artes Visuales Fundación Helga de Alvear, 2016, p. 28.

14. "El existenciario Mitsein indica la relación que el Dasein mantiene constitutivamente con los otros en cuanto estar-en-el-mundo [...]. Heidegger rechaza tajantemente las nociones tradicionales de 'yo', 'sujeto', 'conciencia' entendidas como regiones cerradas y autónomas que permanecen idénticas a través del cambio de comportamientos y vivencias (...). La estructura ontológica del Mitsein indica esa mutua reciprocidad entre el Dasein y los otros", Jesús ADRIÁN ESCUDERO, El lenguaje de Heidegger, Barcelona, Herder, 2009, p. 130.

15. Peter SLOTERDIJK, Esferas III. Espumas. Esferología plural, Valencia, Pre-Textos, 2006.

16. "Parafraseando los esclarecedores conceptos del filósofo Peter Osborne sobre este tema : el arte contemporáneo nos muestra la falta de un tiempo y un espacio (globales). Es más, proyecta una unidad ficticia sobre una variedad de ideas diferentes del espacio y del tiempo, proporcionando una superficie común allí donde no la hay [...]. Este es el rol del arte 
contemporáneo. [...] El arte contemporáneo es un tipo de capa o sustituto que simula que todo está bien, mientras que las personas sufren los efectos de las políticas de shock. [...] Tanto las naciones como los museos son solamente otro modo de organizar el tiempo y el espacio; destrozándolos en pedazos. ¿Pero no son destrozados el tiempo y el espacio cada vez que es creado un nuevo paradigma de museo ?", Hito STEYERL, Arte duty free, Op. cit., p. 112-131.

17. Brois GROYS, Google: Words beyond Grammar, Kassel und Ostfildern: Documenta und Museum Fridericianum Veranstaltungs-GmbH, und Hatje Cantz Verlag, 2011, p. 11.

18. Friedrich NIETzSCHE, Crepúsculo de los ídolos, Madrid, Alianza, 2006.

19. Martin HEIDEGGER, Ser y tiempo, Madrid, Trotta, 2003.

20. Graham HaRman, Tool-Being. Heidegger and the Metaphysics of Objects, Chicago and La Salle, Illinois, Open Court, 2002.

21. Graham HARMAN, Hacia el realismo especulativo, Buenos Aires, Caja Negra, 2015.

22. Graham HARMAN, El objeto cuádruple. Una metafísica de las cosas después de Heidegger, Barcelona, Anthropos, 2016, p. 35-40.

23. Martin HEIDEGGER, Ser y tiempo, Op cit., p. 97 y siguientes. También puede consultarse el libro de Arturo LEYTE, Heidegger, Madrid, Alianza, 2005, p. 103, o la biografía de Safranski sobre Heidegger que aborda, también, su pensamiento : Rüdiger SAFRANSKI, Un maestro de Alemania. Heidegger y su tiempo, Barcelona, 1997, p. 193.

24. Graham HARMAN, El objeto cuádruple, Op. cit., 2016, p. 35-40.

25. Citado en Hito STEYERL, Los condenados de la pantalla, Buenos Aires, Caja Negra, 2018, p. 57.

26. Graham HARMAN, Hacia el realismo especulativo, Op. cit., p. 36.

27. Emmanuel LÉVINAS, Totalidad e infinito, Salamanca, Sígueme, 2012, p. 141 y siguientes.

28. Boris GROYS, Volverse público. Las transformaciones del arte en el ágora contemporánea, Buenos Aires, Caja Negra, 2018, p. 108.

29. Quentin MeILlassoux, Hiper-caos, Holobionte Ediciones, Barcelona, 2018.

30. Graham HARMAN, Hacia el realismo especulativo, Op. cit., p. 298.

31. Ibíd., p. 299.

32. Chus MARTínez, "What is art", en Jens hoffMANn, Ten Fundamental Questions of Curating, Milan, Mousse Publishing, p. 50 y siguientes.

33. Eric SADIN, La silicolonización del mundo, Buenos Aires, Caja Negra, 2018.

34. Quentin MEILlassoux, Después de la finitud. Ensayo sobre la necesidad de la contingencia, Buenos Aires : Caja Negra, 2015, p. 180.

35. Ibid., p. 53.

36. Chus MARTínez, "Me celebro y me canto. El anacronismo como método", Índex. Investigación artística, pensamiento y educación, Revista semestral, Primavera 2011, número 1, Barcelona, MACBA, p. 6-7.

37. Hito STEYERL, Arte duty free..., Op. cit., p. 49-51.

38. Ed finN, La búsqueda del algoritmo, Barcelona, Alpha Decay, 2018, p. 23-25.

39. Sobre el glitch como error algorítmico que permite romper con el pantalla-centrismo, puede consultarse el libro de Scott CONTRERAS-KOTERBAY y Łukasz miroscha, The New Aesthetic and Art: Constellations of the postdigital, Amsterdam, Institute of Network Cultures, 2016, p. 85-86.

40. Además de las conferencias publicadas en su canal de Youtube sobre el Realismo especulativo, puede consultarse al respecto el libro de Ernesto CASTRO, Realismo Postcontinental. Ontología y epistemología para el siglo XXI, Segovia, Materia Oscura, 2020.

41. Sobre las implicaciones del paso atrás en Heidegger, véase: Teresa OÑATE, "Estudio preliminar. Heidegger, Hó Skoteinós (El obscuro). La ontología estética del espacio-tiempo tras la Kehre", Teresa oÑATE, Óscar cuBo y Amanda NÚÑEZ (eds.), El segundo Heidegger. Ecología. Arte. Teología, Madrid, Editorial Dykinson, 2012, p. 22-23. 
42. Boris GROYS, Arte en flujo, Op. cit., p. 68-69.

43. Boris GROYS, Volverse público, Op. cit., p. 24.

44. Brois GroYs, Arte en flujo, Op. cit., p. 62-67.

45. "Al menos desde comienzos del siglo XX, la vanguardia histórica trató de tematizar y revelar la dimensión factual, material, no ficcional del arte. [...] Es justamente esto lo que Intenet alteró de manera radical. Internet funciona bajo la presuposición de su carácter no ficcional (...) Por supuesto que hay blogs y páginas especializadas en arte. Sin embargo, para acceder a ellas, el usuario debe clickear y así enmarcarlas en la superficie de la computadora, el iPad o el teléfono celular. Por lo tanto, el marco se desinstitucionaliza y la ficcionalidad enmarcada se desficcionaliza. El usuario no puede obviar el marco porque lo ha creado. El marco -y la operación de producirlo- se vuelven algo explícito, algo que se mantiene así en la experiencia de la contemplación y la escritura“, Ibíd., p. 197-198.

46. "Hoy en día el artista se preocupa cada vez más por la exposición de su cuerpo como un cuerpo-para-el-trabajo [...]. Abramović tematizó la increíble disciplina, resistencia y esfuerzo físico que se requiere para simplemente estar presente en el lugar de trabajo desde el comienzo y hasta el fin del horario laboral. (...) Incluso la persona más típica y 'normal' hoy documenta permanentemente su cuerpo-para-el-trabajo a través de la fotografía, el video, los sitios web y demás”, Boris GROYS, Volverse público, Op. cit., p. 127-130.

47. "Una exhibición que utiliza la Web y otros medios digitales hace visible el aspecto material y físico de estos medios, su hardware, la materia de la que están hechos. Toda la maquinaria que ingresa en el campo de visión del visitante destruye así la ilusión de que todo lo que es importante en el universo de lo digital tiene lugar solo en la pantalla. $\mathrm{O}$, lo que es incluso más importante : otros visitantes interrumpen el campo de visión del espectador o espectadora. Así, el visitante toma conciencia de que está siendo observado por otros", Boris GROYs, Arte en flujo, Op. cit., p. 153.

48. Boris GROYS, Volverse público, Op. cit., p. 62.

49. Boris GROYs, Arte en flujo, Op. cit., p. 70.

50. Gianni vattimo, Creer que se cree, Barcelona, Paidós Ibérica, 2004.

51. Boris GROYS, Volverse público, Op. cit., p. 173-174.

52. François Jullien, Del "tiempo". Elementos de una filosofía del vivir, Madrid, Arena Libros, 2006, p. 161 y siguientes.

53. Boris GROYS, Arte en flujo, Op. cit., p. 46-53.

54. Boris GROYS, Volverse público, Op. cit., p. 109.

55. "Art having a future means that art has a continuity, which is different from saying that art is the producer of a future, of its idea. [...] The future is a completely different question. It does not require a perfect time and space, but the production of the very fabric of time. The future of art is, therefore, related to the question of duration, to the conditions under which art is continuously made, to its history. The future of art is the same as its end, a matter of language", Chus MARTÍNEZ, "What is art", Op. cit., p. 43.

56. Chus MARTÍNEZ, Elise LAMMER y Rosa LLEó, (eds), El futuro no es lo que va a pasar, sino lo que vamos a hacer, Madrid, ARCOmadrid/IFEMA, Feria de Madrid, Nero. p. 22.

57. Hito STEYERL, Los condenados de la pantalla, Op. cit., p. 161.

58. Boris GROYS y Vittorio HÖSLE, Op. cit., p. 48-49.

59. Boris GROYS, Arte en flujo, Op. cit., p. 73.

60. Ibid., p. 73.

61. William FAULKNER, El ruido y la furia, Madrid, Alianza Editorial, 2004.

62. "Precisamente porque el mundo moderno está saturado del ruido de los mensajeros de los partidos de poder y de los estruendos artísticos del genio, que llaman la atención sobre sus obras y sistemas delirantes, la diferencia religiosa ya no puede señalarse convincentemente desde la 
figura del embajador. El Dios presente no puede alcanzar a los mortales como enviado, sino solo como idiota", Peter SLOTERDIJK, Esferas I, Madrid, Siruela, 2009, p. 426.

63. Hito STEYERL, Arte duty free, Op. cit., p. 145-147.

64. Gianni vattimo y Santiago zaBAla, Comunismo hermenéutico. De Heidegger a Marx, Barcelona, Herder, 2012, p. 17-18.

65. "Para rechazar una categoría, por ejemplo los trabajadores o las mujeres, la calidad de los sujetos políticos, tradicionalmente bastó con constatar que pertenecían a un espacio 'doméstico', a un espacio separado de la vida pública, de donde solo podían emerger gemidos o gritos que expresan sufrimiento, hambre o cólera, pero no discursos que manifiestan una aisthesis común. $Y$ la política de esas categorías [...] consistió en hacer ver lo que no se veía, en entender como palabra lo que solo era audible como ruido", Jacques RANCIÈRE, "Diez tesis sobre la política", en Política, policía, democracia, Santiago de Chile, LOM, 2006, p. 73.

66. Hito STEYERL, Arte duty free, Op. cit, p. 75.

67. Ibid., p. 148-150.

68. Ludwig WITTGENSTEIN (2002), Tractatus logico-philosophicus, Madrid, Tecnos, p. 276.

69. Fragmento basado en un texto incluido en la exposición Desire path, del artista Giacomo Santiago Rogado, inaugurada en el Kunstmuseum Solothurn en 2019: Miguel F. CAMPóN, "The Extreme Slowness of Color and Shape", Miguel F. CAMPón y Christoph VöGELE, Desire path, Viena, VfmK Verlag für moderne Kunst GmbH, 2019, p. 104-105.

\section{RESÚMENES}

El artículo, a modo de manifiesto, expone los fundamentos conceptuales de ARAN (Augmented Reality Art Network), desplegados, hasta el momento, en la exposición de Realidad Aumentada Time and Umwelt (2018), primer recorrido urbano de obras virtuales geolocalizado en España, y en la conferencia-performance Hacerlo explícito, cuya versión corregida presentamos aquí. Desarrollando conceptos pertenecientes a filósofos como Boris Groys (metanoia, kénosis), Jakob von Uexküll (Umwelt), Graham Harman (caricaturización heideggeriana del ser-a-la-mano, prehensión), Quentin Meillassoux (correlacionismo, ancestralidad), por artistas como Hito Steyerl (spam), Harun Farocki (bombas suicidas) o por comisarias como Chus Martínez (principio de indiferencia, futuro, anacronismo), exploramos las relaciones de ARAN con las nuevas tecnologías de Realidad Virtual, desde enfoques polilógicos que realizan un giro respecto al tiempo lineal metafísico-moderno, planteando un arte XR que no renuncia a la complejidad de lo múltiple y que acepta la ausencia de sincronización de un mundo sin nosotros.

L'article, en tant que manifeste, expose les fondements conceptuels de l'ARAN (Augmented Reality Art Network), déployé jusqu'à présent dans l'exposition de Réalité Augmentée Time et Umwelt (2018), la première tournée urbaine d'œuvres virtuelles géolocalisées en Espagne, et dans la conférence-performance Rendre explicite, dont nous présentons ici la version corrigée. En proposant de développer des concepts appartenant à des philosophes tels que Boris Groys (métanoïa, kénose), Jakob von Uexküll (Umwelt), Graham Harman (caricaturisation heideggerienne de l'être à portée de main, préhension), Quentin Meillassoux (corrélationnisme, ancestralité), par des artistes tels que Hito Steyerl (spam), Harun Farocki (attentats suicides) ou par des commissaires comme Chus Martínez (principe d'indifférence, futur, anachronisme), nous explorons les relations de l'ARAN avec les nouvelles technologies de réalité virtuelle, à partir 
d'approches polylogiques qui bouleversent notre rapport au temps linéaire métaphysiquemoderne, posant un art XR qui ne renonce pas à la complexité du multiple et qui accepte l'absence de synchronisation d'un monde sans nous.

The article, as a manifesto, exposes the conceptual foundations of ARAN (Augmented Reality Art Network), deployed, so far, in the exhibition of Augmented Reality Time and Umwelt (2018), the first urban tour of geolocated virtual works in Spain, and in the conference-performance Make it explicit, whose corrected version we present here. Developing concepts belonging to philosophers such as Boris Groys (metanoia, kenosis) Jakob von Uexküll (Umwelt), Graham Harman (heideggerian caricaturization of being-at-hand, prehension), Quentin Meillassoux (correlationism, ancestrality), by artists such as Hito Steyerl (spam), Harun Farocki (suicide bombs) or by curators such as Chus Martínez (principle of indifference, future, anachronism), we explore ARAN's relations with the new Virtual Reality technologies, from polylogical approaches that make a turn with respect to linear time Metaphysical-modern, posing an XR art that does not renounce the complexity of the multiple and that accepts the absence of synchronization of a world without us.

\section{ÍNDICE}

Mots-clés: art virtuel, Umwelt, temps, Boris Groys, Hito Steyerl, Chus Martínez

Palabras claves: arte virtual, Umwelt, tiempo, Boris Groys, Hito Steyerl, Chus Martínez

Keywords: virtual art, Umwelt, time, Boris Groys, Hito Steyerl, Chus Martínez

\section{AUTORES}

MIGUEL F. CAMPÓN

(ARAN)

JOSÉ D. PERIÑÁN

(ARAN) 